\title{
STUDI KOMPARASI ANGKA KUMAN UDARA PADA RUANG PERAWATAN KELAS III DI IRNA II RSUD PROF. DR. MARGONO SOEKARJO PURWOKERTO TAHUN 2014
}

\author{
Muhammad Fuad *), Priyo Santoso, SKM., M.Kes**)
}

Abstract

The Hospital of Prof. Dr. Margono Soekarjo Purwokerto is a type B regional hospital that provides specialist medical care and subspecialty limited. Treatment Room at IRNA II Class III is room surgical treatment for the disease, so that the potential occurrence of nosocomial infections. The purpose of this study was to determine whether there are differences in the numbers of germs existing air in 6 types of class III treatment rooms of IRNA II in hospitals of Prof. Dr. Margono Soekarjo Purwokerto.

This research is an analytic observational study with cross sectional approach. Type variables used were the independent variables (sanitary conditions in the third class ward IRNA II), the dependent variable (number of air germs), potentially confounding variables (temperature, humidity, lighting, ventilation and a wide density residential).

Based on the results of the examination, the average - average rate of 6 indoor air bacteria examined was $157.5 \mathrm{CFU} / \mathrm{m}^{3}$. Average - The average temperature is 29,630 C. Average - average humidity is $69.05 \%$. Average - average is 122.5 Lux lighting. Ventilation holes wide average - average is $13.5 \mathrm{~m}^{2}$. Average occupancy density - average is $17.55 \mathrm{~m}^{3}$.

Researchers concluded in the third class ward IRNA II is not fully qualified fully seen from the quality of the physical environment. Researchers suggest a number of bacteria should be monitored as an indicator of air disinfection room does.

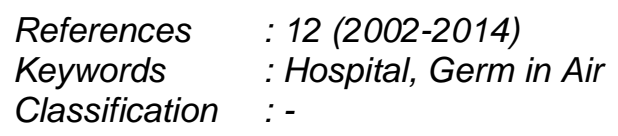

*) Alumni Mahasiswa Jurusan Kesehatan Lingkungan Purwokerto

${ }^{* \star}$ ) Dosen Jurusan Kesehatan Lingkungan Purwokerto

\section{PENDAHULUAN}

\section{A. Latar Belakang}

Pembangunan kesehatan bertujuan untuk meningkatkan kesadaran, kemauan, dan kemampuan hidup sehat bagi setiap orang agar terwujud derajat kesehatan masyarakat yang setinggi-tingginya, sebagai investasi bagi pembangunan sumber daya manusia yang produktif secara sosial dan ekonomis ( UndangUndang Republik Indonesia Nomor 36 Tahun 2009).

Salah satu sarana kesehatan yang memberikan pelayanan kesehatan untuk mempercepat peningkatan derajat kesehatan adalah rumah sakit. Menurut Undang-Undang Republik Indonesia nomor 44 tahun 2009, rumah sakit adalah institusi pelayanan kesehatan yang menyelenggarakan pelayanan rawat inap, rawat jalan, dan gawat darurat. Rumah sakit sebagai institusi pelayanan kesehatan dimana didalamnya terdapat bangunan, peralatan, manusia (petugas, pasien dan pengunjung) dan kegiatan pelayanan kesehatan.

Rumah sakit dapat memberikan dampak positif berupa pelayanan kesehatan yang baik terhadap pasien dan memberikan keuntungan secara ekonomi bagi pemerintah dan rumah sakit itu sendiri, akan tetapi juga dapat menimbulkan dampak negatif berupa pengaruh buruk bagi manusia, seperti sumber penularan infeksi nosokomial. Infeksi nosokomial dapat disebabkan adanya paparan udara ataupun mikroba pathogen yang berasal dari penderita lain di rumah sakit.

Adanya bakteri dalam udara kemungkinan terbawa oleh debu, ataupun terhembus oleh tiupan angin, bakteri yang berasal dari udara misalnya Bacillus $s p$, Staphylococcus sp, Pneumonia, Coloform, Virus Hepatitis, dan Clostridium sp. Maka, kualitas udara rumah sakit yang tidak memenuhi persyaratan kesehatan dapat menimbulkan gangguan kesehatan terhadap pasien, tenaga yang bekerja menimbulkan gangguan kesehatan terhadap pasien, tenaga yang bekerja dirumah sakit maupun pengunjung rumah sakit sebagaimana yang dijelaskan pada KepMenKes RI Nomor 1335/MENKES/KES/SK/X/2002 tentang standar pengambilan dan pengukuran sampel kualitas udara rumah sakit. Bahwa untuk mewujudkan rumah sakit yang aman, nyaman dan sehat perlu dilakukan pemantauan kualitas udara secara rutin. 
Menurut penelitian yang dilakukan di Rumah Sakit Prof. Dr. Margono Soekarjo, rata-rata angka kuman udara di ruang perawatan di RSUD Prof. Dr. Margono Soekarjo pada pagi hari sebesar 463 CFU (Colony Forming Unit)/ $\mathrm{m}^{3}$, sedangkan pada siang hari sebesar $2.604 \mathrm{CFU} / \mathrm{m}^{3}$. Menurut KepMenKes

1204/MENKES/SK/X/2004 tentang Kesehatan Lingkungan Rumah Sakit, indeks kualitas angka kuman udara diruang perawatan nilai ambang batasnya adalah 200-500 CFU/m³. (Suparmin,2008).

RSUD Prof. Dr. Margono Soekarjo merupakan salah satu Rumah Sakit tipe B yang berada di Purwokerto. Berdasarkan data statistik di bulan Juli tahun 2013 RSUD Prof. Dr. Margono Soekarjo mempunyai nilai BOR (Bed Occupancy Rate) 88,99\% untuk IRNA II). Nilai ideal BOR menurut Depkes (2001) adalah 60-85\%. Ruang perawatan di RSUD Prof. Dr. Margono Soekarjo Purwokerto terdiri dari Instalasi Ruang Rawat Inap (IRNA) dan Instalasi Ruang Rawat Jalan (IRJA). Di IRNA II terdapat 6 jenis ruangan perawatan yaitu Kenanga, Cempaka, Teratai, Seruni, Boegenvil dan Edelwis. Setiap ruang perawatan memiliki fungsi yang berbeda dalam penanganan penyakit pasien. Masing-masing ruang perawatan dibagi tiga jenis kelas ruangan yaitu Kelas I, Kelas II, dan Kelas III. Selama kurun waktu satu tahun terakhir ruang perawatan Kelas III belum pernah dilakukan pengukuran angka kuman udara di ruangan tersebut serta tidak rutin dilakukan desinfeksi pada setiap ruangan.

Berdasarkan pertimbangan pada latar belakang tersebut, penulis tertarik untuk melakukan penelitian dengan mengambil judul " Studi Komparasi Angka Kuman Udara pada Ruang Perawatan Kelas III di IRNA II RSUD Prof. Dr. Margono Soekarjo Purwokerto Tahun 2014".

\section{B. Perumusan Masalah}

Apakah ada perbedaan angka kuman udara pada ruang perawatan kelas III di IRNA II RSUD Prof. Dr. Margono Soekarjo Purwokerto.

\section{Tujuan}

\section{Tujuan Umum}

Mengetahui perbedaan jumlah angka kuman udara pada ruang perawatan kelas III di IRNA II RSUD Prof. Dr. Margono Soekarjo Purwokerto.

2. Tujuan Khusus

a. Menghitung jumlah angka kuman udara pada ruang perawatan kelas III di IRNA II RSUD Prof. Dr. Margono
Soekarjo Purwokerto.

b. Mengukur suhu, kelembaban, pencahayaan, luas lubang ventilasi, dan kepadatan hunian kelas III di IRNA II RSUD Prof. Dr. Margono Soekarjo Purwokerto.

\section{Manfaat Penelitian}

1. Bagi Pemerintah

Dapat digunakan sebagai bahan pertimbangan untuk pelaksanaan program penyehatan lingkungan, khususnya pada tindakan penyehatan udara pada rumah sakit.

2. Bagi Rumah Sakit

Sebagai masukan dan di harapkan dapat membantu rumah sakit dalam melakukan tindakan baik penanganan atau evaluasi jumlah angka kuman udara pada ruang perawatan kelas III di IRNA II, sehingga dapat meminimalisir risiko yang mungkin timbul.

3. Bagi Institusi

Menambah bahan bacaan di perpustakaan kampus 7 Poltekkes Kemenkes Semarang tentang penyehatan udara.

4. Bagi peneliti

Menambah pengetahuan dan keterampilan dalam penulisan karya tulis ilmiah tentang penyehatan.

\section{METODE PENELITIAN}

\section{A. Variabel Penelitian}

1. Jenis Variabel

a. Variabel Bebas

Variabel bebas adalah variabel yang berpengaruh atau yang menyebabkan berubahnya variabel terikat dan merupakan variabel yang diutamakan. Variabel bebas dalam penelitian ini adalah Kondisi sanitasi ruang perawatan kelas III di IRNA II RSUD Prof. Dr. Margono Soekarjo Purwokerto.

b. Variabel terikat

Variabel terikat adalah variabel yang diduga nilainya akan berubah karena adanya pengaruh dari variabel bebas. Variabel terikat dalam penelitian ini adalah angka kuman udara.

c. Variabel Pengganggu

Variabel pengganggu adalah variabel yang diduga berpengaruh terhadap variabel terikat, tetapi dalam penelitian ini tidak diutamakan. Variabel pengganggu dalam penelitian ini adalah suhu, kelembaban, pencahayaan, luas 
lubang ventilasi, dan kepadatan hunian.

2. Struktur Hubungan Variabel

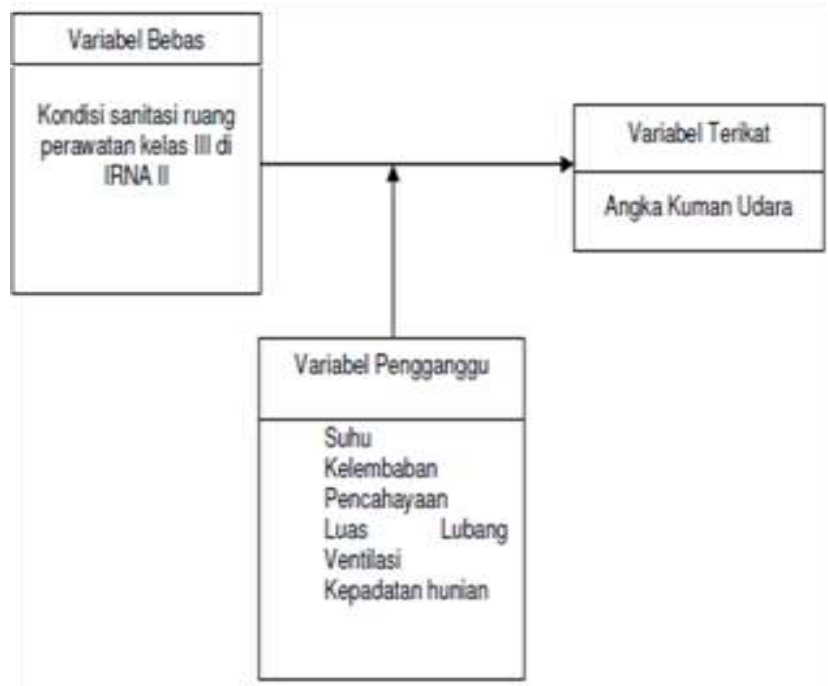

Gambar 2.1 Struktur Hubungan Antar Variabel

\section{B. Jenis Penelitian}

Jenis penelitian yang dilakukan yaitu penelitian observasional analitik dengan metode pendekatan cross sectional yaitu penelitian terhadap angka kuman udara dan lingkungan fisik, yaitu suhu, kelembaban, pencahayaan, luas lubang ventilasi dan kepadatan hunian.

\section{Ruang Lingkup}

1. Waktu

a. Tahap Persiapan : Desember 2013 Februari 2014

b. Tahap Pelaksanaan : Maret 2014 April 2014

c. Tahap Penyelesaian : Mei 2014 Juni 2014

2. Lokasi

Kegiatan penelitian mengambil lokasi pada Ruang Perawatan Kelas III di IRNA II RSUD Prof. Dr. Margono Soekarjo Purwokerto.

3. Materi

Materi dalam penelitian ini adalah Kesehatan Lingkungan dengan bidang kajian Penyehatan Udara mengenai Angka Kuman Udara pada Ruang Perawatan Kelas III di IRNA II RSUD Prof. Dr. Margono Soekarjo Purwokerto.

\section{Populasi dan Sampel}

1. Populasi

Populasi dalam penelitian ini adalah Ruang Perawatan kelas III di IRNA II yang berjumlah 12 ruangan.

2. Sampel

Sampel pada penelitian ini Ruang

Perawatan kelas III di IRNA II yang berjumlah 6 ruangan.

\section{E. Pengumpulan Data}

1. Jenis Data

a. Data Umum

Gambaran umum mengenai RSUD Prof. Dr. Margono Soekarjo Purwokerto meliputi sejarah berdirinya, struktur organisasi, fasilitas pelayanan, tenaga pelaksana dan kapasitas tempat tidur.

b. Data Khusus

Gambaran umum mengenai ruang perawatan kelas III di IRNA II RSUD Prof. Dr. Margono Soekarjo Purwokerto meliputi jumlah angka kuman udara, suhu, kelembaban, pencahayaan, luas lubang ventilasi, dan kepadatan hunian.

2. Sumber Data

a. Data Primer

Data primer diperoleh peneliti dari hasil pengukuran, wawancara dan observasi menggunakan checklist pada ruang perawatan yang ada di RSUD Prof. Dr. Margono Soekarjo Purwokerto.

b. Data Sekunder

Data sekunder diperoleh peneliti dari profil ruang perawatan kelas III di IRNA II RSUD Prof. Dr. Margono Soekarjo Purwokerto.

3. Cara Pengumpulan Data

a. Wawancara

Pengumpulan data dengan melakukan serangkaian tanya jawab dengan petugas IPL (Instalasi Pengelolaan Lingkungan) bagaimana pelaksanaan pengukuran angka kuman dan pelaksanaan desinfeksi pada ruang perawatan kelas III di IRNA II RSUD Prof. Dr. Margono Soekarjo Purwokerto.

b. Observasi

Pengumpulan data secara langsung dengan mengamati kondisi sanitasi ruang perawatan kelas III di IRNA II RSUD Prof. Dr. Margono Soekarjo Purwokerto.

c. Pengukuran

Penelitian yang saya lakukan dengan cara mengukur jumlah angka kuman udara, suhu ruangan, kelembaban udara, pencahayaan, dan luas lubang ventilasi, di ruang perawatan kelas III di IRNA II RSUD Prof. Dr. Margono Soekarjo Purwokerto.

d. Pemeriksaan laboratorium

Menghitung jumlah angka kuman udara yang di peroleh dari pemeriksaan sampel udara di ruang 
perawatan kelas III di IRNA II RSUD

Prof. Dr. Margono Soekarjo

Purwokerto.

4. Instrumen Pengumpulan Data

a. Checklist

Daftar pertanyaan yang

digunakan untuk observasi. Checklist dapat dilihat pada lampiran.

b. Kuesioner

Wawancara dilakukan kepada petugas IPL dengan menggunakan kuisioner meliputi metode yang digunakan untuk desinfeksi, alat yang digunakan untuk desinfeksi ruangan, bahan aktif apa yang terkandung dalam desinfektan.

c. Pengukuran

Melakukan pengukuran yang meliputi pengukuran suhu ruangan dengan menggunakan termometer, kelembaban udara dengan menggunakan hygrometer, pencahayaan dengan menggunakan luxmeter, dan angka kuman di udara dengan menggunakan inpinger melalui media cair.

d. Pemeriksaan Laboratorium

Menghitung jumlah angka kuman udara yang di peroleh dari pengambilan sampel udara di ruang perawatan kelas III di IRNA II RSUD Prof. Dr. Margono Soekarjo Purwokerto.

\section{F. Analisis Data}

Analisis yang digunakan dalam penelitian ini adalah analisis univariat dan analisis bivariat dengan menggunakan uji $t$ test (post-post), yaitu uji beda dua mean data tidak berpasangan (dependent) dengan bantuan software SPSS seri 17.00.

1. Analisis Univariat

Analisis ini diperlukan untuk mendiskripsikan hasil, pengukuran serta menyajikan dalam bentuk tabel, narasi atau grafik.

2. Analisis Bivariat

Analisis Bivariat utuk menguji perbedaan menggunakan uji annova dengan menganalisis data menggunakan software statistik.

\section{HASIL}

\section{A. Data Umum RSUD Prof. Dr. Margono Soekarjo Purwokerto}

Rumah Sakit Umum Daerah Prof. Dr. Margono Soekarjo (RSMS) Purwokerto merupakan salah satu rumah sakit yang berada di Kabupaten Banyumas.Dahulu bernama Rumah sakit Umum (RSU)
Purwokerto yang didirikan oleh pabrik gula milik Belanda pada tahun 1916. RSU Purwokerto berturut-turut dimiliki oleh Belanda dan Jepang, pada waktu itu Belanda dan Jepang masih Menjajah Indonesia yang kemudian setelah Indonesia merdeka, RSU Purwokerto dikelola oleh pemerintah Indonesia.

RSUD Prof. Dr. Margono Soekarjo Purwokerto menempati bangunan di atas areal tanah seluas 11,5 ha, tepat di pintu masuk Purwokerto dari arah timur. Bangunan rumah sakit ini dibangun secara bertahap sejak tahun 1961 sampai tahun 1965 dan difungsikan pada tanggal 10 juli 1995 untuk kegiatan Poliklinik, Instalasi Gawat Darurat, Instalasi Laboratorium, Instalasi Farmasi, dan Instalasi Radiologi. Pada tanggal 12 Oktober 1995 semua kegiatan pelayanan telah dapat berfungsi seluruhnya di RSUD Prof. Dr. Margono Soekarjo Purwokerto di Jalan Dr. Gumbreg Nomor 1 Purwokerto.

Berdasarkan surat Keputusan DPRD Dati II Banyumas pada tanggal 3 September 1961 No. 3/5/V/DPRD/1961, nama RSU Purwokerto diganti menjadi RSUD Prof. Dr. Margono Soekarjo Purwokerto. Sebelumnya RSUD Prof. Dr. Margono Soekarjo Purwokerto merupakan RSU dengan tipe $C$ yang kemudian meningkat menjadi tipe $B$ bersama dengan dikeluarkannya SK Menkes RI No. 41/MENKES/SK/I/1987, tanggal 21 Januari 1967 tentang peningkatan RSU Purwokerto dari tipe $C$ menjadi tipe $B$, yang kemudian ditindak lanjuti dengan SK Gubernur Kepala Daerah Tingkat I Jawa Tengah No.061.1/091 tanggal 5 Mei 1988maka secara resmi RSU Purwokerto menjadi tipe B.

Pada tahun 2001 dengan SK Menkes No. 239/Menkes- Kesos/SK/III/2001 tanggal 23 Maret, RSUD Prof. Dr. Margono Soekarjo Purwokerto telah ditetapkan sebagai Rumah Sakit Umum Tipe B Pendidikan. Mengikuti penetapan kelas B Pendidikan maka diterbitkan PERDA Nomor 06 Tahun 2006 dan PERGUB Nomor 34 Tahun 2006 tentang penjabaran tugas pokok dan fungsi sera tata kerja RSUD Prof. Dr. Margono Soekarjo Purwokerto.

Sebagai Rumah Sakit Tipe B Pendidikan, RSUD Prof. Dr. Margono Soekarjo Purwokerto berperan sebagai rumah sakit rujukan tingkat kedua bagi institusi pelayanan kesehatan yang lebih rendah disekitarnya.Dengan pelayanan kesehatan paripurna yang terjangkau sesuai dengan tuntutan masyarakat, serta melaksanakan pendidikan profesi kedokteran dan profesi kesehatan lainnya. 
Jenis tenaga kerja di RSUD Prof. Dr. Margono Soekarjo Purwokerto adalah tenaga kerja Pegawai Negeri Sipil (PNS) dan tenaga kerja Pegawai Sipil Non PNS. Jumlah tenaga kerja di RSUD Prof. Dr. Margono Soekarjo Purwokerto tersaji pada tabel 3.1 sebagai berikut :

Tabel 3.1: Jumlah dan Jenis Tenaga Kerja di RSUD Prof. Dr. Margono Soekarjo Purwokerto Tahun 2014

\begin{tabular}{|c|c|c|}
\hline No. & Jenis Tenaga Kerja & $\begin{array}{l}\text { Jumlah } \\
\text { (orang) }\end{array}$ \\
\hline 1. & Dokter Umum & 25 \\
\hline 2. & Dokter spesialis Rehabilitasi Medik & 2 \\
\hline 3. & Dokter spesialis Anestesi & 5 \\
\hline 4. & Dokter spesialis Radiologi & 2 \\
\hline 5. & Dokter spesialis Kulit Kelamin & 3 \\
\hline 6. & Dokter spesialis Anak & 6 \\
\hline 7. & Dokter spesialis Mata & 4 \\
\hline 8. & Dokter spesialis Patologi Klinik & 1 \\
\hline 9. & Dokter spesialis Patologi Anatomi & 2 \\
\hline 10. & $\begin{array}{l}\text { Dokter spesialis Kandungan dan } \\
\text { Kebidanan }\end{array}$ & 41 \\
\hline 11. & Dokter spesialis Bedah Orthopaedi & 4 \\
\hline 12. & Dokter spesialis Bedah Saraf & 2 \\
\hline 13. & Dokter spesialis THT & 3 \\
\hline 14. & Dokter spesialis Kesehatan Jiwa & 1 \\
\hline 15. & Dokter spesialis Orthodensi & 1 \\
\hline 16. & Dokter Gigi & 3 \\
\hline 17. & Dokter spesialis Paru & 3 \\
\hline 18. & Dokter Saraf & 4 \\
\hline 19. & Dokter Penyakit Dalam & 4 \\
\hline 20. & Medis & 75 \\
\hline 21. & Dokter Bedah Onkologi & 1 \\
\hline 22. & Apoteker & 8 \\
\hline 23. & Tenaga Kesehatan Masyarakat & 12 \\
\hline 24. & Tenaga Gizi & 15 \\
\hline 25. & Farmasi & 62 \\
\hline 26. & Tenaga Keperawatan & 603 \\
\hline 27. & Bidan & 41 \\
\hline 28. & Psikologi & 1 \\
\hline 29. & Dokter Bedah Mulut & 1 \\
\hline 30. & Tenaga Kefarmasian & 66 \\
\hline 31. & Obsgyn & 6 \\
\hline 32. & $\begin{array}{l}\text { DIII Sanitasi + D IVSarjana Sains } \\
\text { Terapan }\end{array}$ & 9 \\
\hline 33. & DIII Anaestesi & 5 \\
\hline 34. & DIII Fisioterapi & 7 \\
\hline 35. & D IV Fisika Medis & 75 \\
\hline 36. & Radiografer + DIII Radiologi & 23 \\
\hline 37. & Teknisi elektromedik & 6 \\
\hline 38. & Analis Kesehatan & 39 \\
\hline 39. & Konsultan Fetomartenal & 1 \\
\hline 40. & Konsultan Infertilitas & 1 \\
\hline 41. & Konsultan Nephrologi & 1 \\
\hline 42. & Tenaga Administrasi & 657 \\
\hline \multicolumn{2}{|c|}{ Jumlah } & 1850 \\
\hline
\end{tabular}

Sumber : Profil Pedoman Mutu RSMS Januari 2014

RSUD Prof. Dr. Margono Soekarjo Purwokerto terdapat dua jenis perawatan yaitu rawat inap (IRNA) dan rawat jalan
(IRJA), selain itu terdapat juga unit penunjang medis dan non medis, serta terdapat juga poliklinik. RSUD Prof. Dr. Margono Soekarjo Purwokerto pada tahun 2014 kapasitas tempat tidur sebanyak 676 buah, terbagi dalam 5 (lima) Instalasi, yaitu Instalasi Rawat Inap 1, Instalasi Rawat Inap 2, Instalasi Abiyasa, Instalasi Maternal Perinatal dan Instalasi Perawatan Intensif yang terbagi dalam beberapa kelas. Untuk lebih jelasnya data kelas dan jumlah tempat tidur tersaji pada tabel 3.2 sebagai berikut: Tabel 3.2: Data Kelas dan Jumlah Tempat Tidur RSUD Prof. Dr. Margono Soekarjo Purwokerto Tahun 2014

\begin{tabular}{|l|l|c|}
\hline No. & \multicolumn{1}{|c|}{ Kelas } & $\begin{array}{c}\text { Jumlah Tempat } \\
\text { Tidur }\end{array}$ \\
\hline 1. & VIP A & 85 \\
\hline 2. & Utama & 26 \\
\hline 3. & Kelas I & 70 \\
\hline 4. & Kelas II & 116 \\
\hline 5. & Kelas III & 325 \\
\hline 6. & ICU & 13 \\
\hline 7. & HCU & 33 \\
\hline 8. & ICCU & 4 \\
\hline 9. & NICU & 2 \\
\hline \multicolumn{2}{|c|}{ Jumlah } & 676 \\
\hline
\end{tabular}

Sumber : Profil Pedoman Mutu RSMS Januari 2014

Struktur Organisasi dan Tata Kerja RSUD Prof. Dr. Margono Soekarjo Purwokerto didasarkan pada Perda Provinsi Jawa Tengah Nomor 8 Tahun 2008 diatur sebagai berikut :

1. Organisasi rumah Sakit dipimpin oleh Direktur

2. Direktur dibantu oleh 3 (tiga) Wakil Direktur, yaitu Wakil Direktur Umum dan Keuangan, Wakil Direktur Pelayanan dan Kerjasama serta Wakil Direktur Penunjang dan Pendidikan

3. Wakil Direktur Umum dan Keuangan membawahi :

a. Bagian Umum, dibantu 3 (tiga) Sub Bagian

b. Bagian Perencanaan, dibantu 3 (tiga) Sub Bagian

c. Bagian Keuangan, dibantu 3 (tiga) Sub Bagian

4. Wakil Direktur Pelayanan dan Kerjasama membawahi :

a. Bidang Pelayanan, dibantu 2 (dua) Seksi Pelayanan

b. Bidang Perawatan, dibantu 2 (dua) Seksi Perawatan

5. Wakil Direktur Penunjang dan Pendidikan membawahi :

a. Bidang Penunjang Medik, dibantu 2 (dua) Seksi PenunjangTerapi dan Seksi Penunjang Diagnostik 
b. Bidang Sarana dan Prasarana RS, dibantu 2 (dua) Seksi Sarpras Medik dan Seksi Sarpras Non Medik

c. Bidang Pendidikan dan Pelatihan, dibantu 2 (dua) Seksi Pendidikan dan Pelatihan

6. Non Struktural
a. Instalasi
b. Komite Keperawatan
c. Komite Medis
d. Staf Medis Fungsional
e. Satuan Pengawas Intern

Fasilitas pelayanan yang ada di RSUD

Prof. Dr. Margono Soekarjo Purwokerto adalah sebagai berikut :

1. Instalasi Medis
a. Instalasi Rawat Jalan (22 Poliklinik VCT \& PTRM)
b. Instalasi Rawat Inap ( 14 Ruang perawatan)
c. Instalasi Perawatan Intensif (ICU, ICCU, $\mathrm{HCU}$ )
d. Instalasi Bedah Sentral (10 Kamar Operasi)
e. Instalasi Gawat Darurat
f. Instalasi Rehabilitasi Medik
g. Instalasi Radiologi (Radiodiagnostik dan Radioterapi
h. Instalasi Patologi Klinik
i. Instalasi Patologi Anatomi
j. Instalasi Farmasi
k. Instalasi Haemodialisa (21 Mesin HD)
I. Instalasi Transfusi Darah

2. Instalasi Non Medis
a. Instalasi PLRS, IPSRS, ICPH
b. Instalasi Gizi, Forensik, Ambulance
c. Instalasi Maternal Perinatal

3. Unit Media Fungsional (UMF) atau

Poliklinik
a. Poli Bedah
b. Poli Jantung
c. Poli Gigi dan Mulut
d. Poli Kebidanan dan Penyakit kandungan
e. Poli Kesehatan Anak
f. Poli Kulit dan Kelamin
g. Poli Mata
h. Poli Paru
i. Poli Penyakit Dalam
j. Poli syaraf
k. Poli THT

RSUD Prof. Dr. Margono Soekarjo Purwokerto terdapat instalasi penyehatan lingkungan yang bertugas untuk mengolah limbah cair, mengolah limbah padat, pengawasan hygiene sanitasi makanan, pengawasan kualitas air bersih, pengawasan sanitasi ruang bangun, pelaksana laboratorium kesehatan lingkungan dan pengendalian vector, serangga, kucing, dan tikus.
Dalam pelaksanaan tugasnya kepala instalasi dibantu oleh staf pelaksana diantaranya :

1. Pelaksana kepala sub instalasi sanitasi

2. Pelaksana kepala sub instalasi kesehatan lingkungan

3. Pelaksana kepala sub instalasi laboratorium kesehatan lingkungan

4. Pelaksana administrasi dan logistic

5. Pelaksana penyehatan air bersih

6. Pelaksana kepala makanan dan minuman

7. Pelaksana laboratorium

8. Pelaksana pengolahan limbah padat

9. Pelaksana penyehatan ruang dan bangunan

10.Pelaksana pengendalian serangga dan vector

11.Pelaksana pekerja rumah tangga

\section{B. Data Khusus}

1. IRNA II di RSUD Prof. Dr. Margono Soekarjo Purwokerto

RSUD Prof. Dr. Margono Soekarjo Purwokerto terdapat dua jenis perawatan yaitu rawat inap (IRNA) dan rawat jalan (IRJA), selain itu terdapat juga unit penunjang medis dan non medis.Instalasi Rawat Inap (IRNA) dibagi menjadi 2 bagian, yaitu IRNA I dan IRNA II.

IRNA II adalah Instalasi rawat Inap yang memberikan pelayanan medis bedah dimana pasien yang opname di IRNA II mengalami pembedahan dalam tubuhnya seperti pemasangan PEN, penyakit tumor yang harus menjalani pembedahan dan masih banyak lagi.Perbedaan dari IRNA I dengan IRNA II adalah pada penanganan penyakitnya, jika IRNA I memberikan pelayanan kesehatan non bedah seperti penyakit thypoid, HIV, Hepatitis, Diare dan lain-lain yang pada intinya tidak mengalami pembedahan, maka IRNA II khusus memberikan pelayanan pada penyakit bedah.

Berikut ini adalah ruangan kelas III yang terdapat di IRNA II :

Tabel 3.3 : Jumlah Ruangan dan Tempat Tidur Pada Ruang Perawatan Kelas III di IRNA II RSUD Prof. Dr. Margono Soekarjo Purwokerto Tahun 2014

\begin{tabular}{|l|l|c|}
\hline No. & Nama Ruangan & $\begin{array}{c}\text { Jumlah Tempat } \\
\text { Tidur }\end{array}$ \\
\hline 1. & Kenanga & $8-10$ bed \\
\hline 2. & Cempaka & $8-10$ bed \\
\hline 3. & Seruni & $8-10$ bed \\
\hline 4. & Teratai & $8-10$ bed \\
\hline 5. & Edelweis & $8-10$ bed \\
\hline 6. & Bougenvil & $8-10$ bed \\
\hline
\end{tabular}


Berikut adalah struktur oorganisasi pelayanan keperawatan RSUD Prof. Dr. Margono Soekarjo Purwokerto instalasi rawat inap II

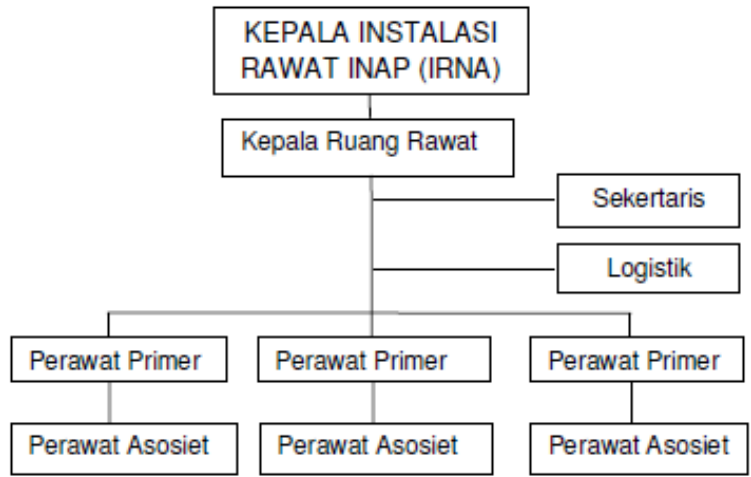

Gambar 3.1 Struktur Organisasi IRNA II Prof. Dr. Margono Soekarjo Purwokerto Tahun 2013

2. Ruang Perawatan Kelas III di IRNA II Ruang perawatan kelas III yang ada di IRNA II adalah ruang perawatan dengan kapasitas bed paling banyak. Dari ketiga kelas yang ada di IRNA II, kelas III merupakan ruangan yang paling luas dengan kapasitas 8-10 bed tiap ruangan. Luas ruang perawatan kelas III yaitu berukuran 10 meter $\times 6$ meter dengan tinggi 3 meter.Dari ke enam jenis ruangan yang ada di IRNA II, ruang perawatan kelas III berjumlah 12 ruangan dengan rincian ruang kenanga 2 kamar, ruang teratai 2 kamar, ruang cempaka 2 kamar, ruang edelweis2 kamar, dan ruang bougenvil 2 kamar.

Dengan kapasitas bed paling banyak beserta pasien dan penunggunya, maka hal tersebut akan menimbulkan terjadinya perubahan suhu, perubahan kelembaban atau bahkan peningkatan jumlah angka kuman udara di ruangan tersebut. Karena pada dasarnya, semakin bertambahnya penghuni dan meningkatnya aktivitas maka dapat juga meningkatkan jumlah angka kuman udara.

Data yang diperoleh dari ruang perawatan kelas III di IRNA II meliputi observasi sanitasi ruang dan kepadatan hunian, serta hasil pengukuran kualitas fisik seperti pengukuran suhu, kelembaban, pencahayaan, luas lubang ventilasi dan pengambilan angka kuman udara yang selanjutnya dilakukan pemeriksaan di laboratorium RSUD Prof.Dr Margono Soekarjo Purwokerto.

Tempat yang digunakan untuk pengambilan angka kuman udara yaitu ruang cempaka kamar 8 , ruang kenanga kamar 7, ruang seruni kamar 7, ruang teratai kamar 8, ruang edelweiss perempuan dan ruang bougenvil kamar 2 , dimana masing masing kamar tersebut adalah ruang perawatan kelas III.

3. Hasil Pengukuran dan Pemeriksaan Angka Kuman Udara

Setelah dilakukan penelitian pada ruang perawatan kelas III di IRNA II, di dapat hasil jumlah angka kuman udara sebagai berikut:

Tabel 3.4 :Angka Kuman Udara Ruang Perawatan Kelas III di IRNA II RSUD Prof. Dr. Margono Soekarjo Purwokerto Tahun 2014

\begin{tabular}{|c|c|c|c|c|c|c|}
\hline \multicolumn{4}{|c|}{ Pengambilan } & \multicolumn{2}{|c|}{ Sebelum Desinfeksi } & \multirow[b]{2}{*}{ Keterangan } \\
\hline No & Tanggal & Jam & Ruangan & Kamar & $\begin{array}{l}\text { Angka } \\
\text { Kuman } \\
\text { (CFUim²) }\end{array}$ & \\
\hline 1. & $21 / 4$ & 12,15 & R. Cempaka & Karnar 8 & 351 & \multirow{5}{*}{$\begin{array}{c}\text { Pasien, } 7 \\
\text { Penunggu } \\
2 \text { Pasien, } 5 \\
\text { Penunggu } \\
2 \text { Pasien, } 3 \\
\text { Penunggu } \\
4 \text { Pasien, 2 } \\
\text { Penunggu } \\
1 \text { Pasien }\end{array}$} \\
\hline 2. & $21 / 4$ & 12.20 & R. Kenanga & Kamar 7 & 104 & \\
\hline 3. & $21 / 4$ & 11.55 & R. Seruni & Kamar 7 & 102 & \\
\hline 4. & $21 / 4$ & 12.05 & R. Teratai & Kamar 8 & 145 & \\
\hline 5 & $21 / 4$ & 12.35 & R. Edelweis & Kamar 3 & 49 & \\
\hline 6 & $21 / 4$ & 12.40 & R. Bougenvil & Kamar 2 & 194 & $\begin{array}{l}5 \text { Pasien, } 4 \\
\text { Penunggu }\end{array}$ \\
\hline & \multicolumn{3}{|c|}{ Rata-rata } & & 157.5 & \\
\hline
\end{tabular}


4. Hasil Pengukuran Kualitas Fisik

Setelah dilakukan pengukuran kualitas fisik yang meliputi suhu, kelembaban, pencahayaan, luas lubang ventilasi, dan kepadatan hunian pada ruang perawatan kelas III di IRNA II, didapat hasil sebagai berikut:

a. Pengukuran Suhu

Tabel 3.5 :Pengukuran Suhu Ruang

Perawatan Kelas III di IRNA II RSUD Prof. Dr. Margono Soekarjo Purwokerto Tahun 2014

\begin{tabular}{|c|c|c|c|c|c|}
\hline \multirow[b]{2}{*}{ No } & \multicolumn{2}{|c|}{ Pengambilan } & \multirow[b]{2}{*}{ Ruangan } & \multirow[b]{2}{*}{ Kamar } & \multirow[b]{2}{*}{ Suhu $\left({ }^{\circ} \mathrm{C}\right)$} \\
\hline & Tanggal & Jam & & & \\
\hline 1. & $21 / 4$ & 11.55 & R. Compaka & Kamar 8 & 30,9 \\
\hline 2. & $21 / 4$ & 12.05 & R. Kenanga & Kamar 7 & 29,3 \\
\hline 3. & $21 / 4$ & 12.15 & R. Seruni & Kamar 7 & 28,4 \\
\hline 4. & $21 / 4$ & 12.20 & R. Teratai & Kamar 8 & 29,3 \\
\hline 5 & $21 / 4$ & 12.35 & $\begin{array}{l}\text { R. Edelweis } \\
\text { Perempuan }\end{array}$ & Kamar 3 & 30,0 \\
\hline 6 & $21 / 4$ & 12.40 & R. Bougenvil & Kamar 2 & 29,9 \\
\hline \multicolumn{5}{|c|}{ Rata-rata } & 29,63 \\
\hline
\end{tabular}

b. Pengukuran Kelembaban

Tabel 3.6 :Pengukuran Kelembaban

Ruang Perawatan Kelas III di

IRNA II RSUD Prof. Dr. Margono Soekarjo

Purwokerto Tahun 2014

\begin{tabular}{|c|c|c|c|c|c|}
\hline \multicolumn{6}{|c|}{ Pengambilan } \\
\hline No & Tanggal & Jam & Ruangan & Kamar & $\begin{array}{c}\text { Kelembaban } \\
(\%)\end{array}$ \\
\hline 1. & $21 / 4$ & 11.55 & R. Cempaka & Kamar 8 & 66,5 \\
\hline 2. & $21 / 4$ & 12.05 & R. Kenanga & Kamar 7 & 70,5 \\
\hline 3. & $21 / 4$ & 12.15 & R. Seruni & Kamar 7 & 68,5 \\
\hline 4. & $21 / 4$ & 12.20 & R. Teratai & Kamar 8 & 68,2 \\
\hline 5 & $21 / 4$ & 12.35 & $\begin{array}{l}\text { R. Edelweis } \\
\text { Perempuan }\end{array}$ & Kamar 3 & 70,3 \\
\hline 6 & $21 / 4$ & 12.40 & R. Bougenvil & Kamar 2 & 70,3 \\
\hline \multicolumn{5}{|c|}{ Rata-rata } & 69,05 \\
\hline
\end{tabular}

c. Pengukuran Pencahayaan

Tabel 3.7 :Pengukuran Pencahayaan

Pada Ruang Perawatan

Kelas IIIdi IRNA IIRSUD

Prof. Dr. Margono Soekarjo

Purwokerto Tahun 2014

\begin{tabular}{|c|c|c|c|c|c|}
\hline \multirow[b]{2}{*}{ No } & \multicolumn{2}{|c|}{ Pengambilan } & \multirow[b]{2}{*}{ Ruangan } & \multirow[b]{2}{*}{ Kamar } & \multirow{2}{*}{$\begin{array}{c}\text { Pencahayaan } \\
\text { (Lux) }\end{array}$} \\
\hline & Tanggal & Jam & & & \\
\hline 1. & $21 / 4$ & 11.55 & R. Cempaka & Kamar 8 & 96 \\
\hline 2. & $21 / 4$ & 12.05 & R. Kenanga & Kamar 7 & 69 \\
\hline 3. & $21 / 4$ & 12.15 & R. Seruni & Kamar 7 & 80 \\
\hline 4. & $21 / 4$ & 12.20 & R. Teratai & Kamar 8 & 159 \\
\hline 5 & $21 / 4$ & 12.35 & $\begin{array}{l}\text { R. Edelweis } \\
\text { Perempuan }\end{array}$ & Kamar 3 & 251 \\
\hline 6 & $21 / 4$ & 12.40 & R. Bougenvil & Kamar 2 & 80 \\
\hline \multicolumn{5}{|c|}{ Rata-rata } & 122,5 \\
\hline
\end{tabular}

d. Pengukuran Luas Lubang Ventilasi

Tabel 3.8 : Pengukuran Luas Lubang Ventilasi Ruang Perawatan Kelas III di IRNA IIRSUD Prof. Dr. Margono Soekarjo Purwokerto Tahun 2014

\begin{tabular}{|c|c|c|c|c|c|c|}
\hline No & Tanggal & Jam & Ruangan & Kamar & $\begin{array}{l}\text { Luas } \\
\text { Lantai }\end{array}$ & $\begin{array}{c}\text { Kepadatan } \\
\text { Hunian } \\
\text { ( } \mathrm{m}^{2} / \text { orang) }\end{array}$ \\
\hline 1. & $21 / 4$ & 13.00 & R. Cempaka & Kamar 8 & $72 m^{2}$ & 4,5 \\
\hline 2. & $21 / 4$ & 13.20 & R. Kenanga & Kamar 7 & $72 \mathrm{~m}^{2}$ & 10,2 \\
\hline 3. & $21 / 4$ & 13.50 & R. Seruni & Kamar 7 & $60 \mathrm{~m}^{2}$ & 12 \\
\hline 4. & $21 / 4$ & 14.25 & R. Teratai & Kamar 8 & $72 \mathrm{~m}^{2}$ & 12 \\
\hline 5 & $21 / 4$ & 14.40 & $\begin{array}{l}\text { R. Edelweis } \\
\text { Perempuan }\end{array}$ & Kamar 3 & $60 \mathrm{~m}^{2}$ & 60 \\
\hline 6 & $21 / 4$ & 14.55 & R. Bougenvil & Kamar 2 & $60 \mathrm{~m}^{2}$ & 6,66 \\
\hline \multicolumn{6}{|c|}{ Rata-rata } & 17,56 \\
\hline
\end{tabular}

e. Perhitungan Kepadatan Hunian Tabel 3.9 Perhitungan Kepadatan Hunian Ruang Perawatan Kelas III di IRNA II RSUD Prof. Dr. Margono Soekarjo Purwokerto 2014

\begin{tabular}{|c|c|c|c|c|c|}
\hline \multirow[b]{2}{*}{ No } & \multicolumn{2}{|c|}{ Pengukuran } & \multirow[b]{2}{*}{ Ruangan } & \multirow[b]{2}{*}{ Kamar } & \multirow[b]{2}{*}{$\begin{array}{l}\text { Luas Lubang } \\
\text { Ventilasi (\%) }\end{array}$} \\
\hline & Tanggal & Jam & & & \\
\hline 1. & $21 / 4$ & 13.00 & R. Cempaka & Kamar 8 & 21,75 \\
\hline 2. & $21 / 4$ & 13.20 & R. Kenanga & Kamar 7 & 13 \\
\hline 3. & $21 / 4$ & 13.50 & R. Seruni & Kamar 7 & 10 \\
\hline 4. & $21 / 4$ & 14.25 & R. Teratai & Kamar 8 & 15,75 \\
\hline 5 & $21 / 4$ & 14.40 & $\begin{array}{l}\text { R. Edelweis } \\
\text { Perempuan }\end{array}$ & Kamar 3 & 9 \\
\hline 6 & $21 / 4$ & 14.55 & R. Bougenvil & Kamar 2 & 11,6 \\
\hline \multicolumn{5}{|c|}{ Rata-rata } & 13,5 \\
\hline
\end{tabular}

5. Desinfeksi

Desinfeksi yang dilakukan di RSUD Prof. Dr. Margono Soekarjo Purwokerto khususnya ruang perawatan menggunakan desinfektan yang mengandung bahan aktif Didecyidimethilammonium chloride, Polyhexamethylene

Biguanide Hydrochloride, dan Dimeticonesatau biasa disebut dengan Aniosdengan alat desinfeksi Hurricane Model 2786 Ultra atau biasa disebut dengan Fogger. Alat tersebut mampu memuat 4 liter desinfektan, Penggunaan bahan aktif tersebut tanpa bahan pengencer sehingga mampu membunuh kuman di udara dengan cepat. Kegiatan desinfeksi ruangan dilaksanakan apabila ada permintaan dari pihak ruangan IRNA II dan ruangan dalam keadaan kosong (tidak terdapat pasien). Hal tersebut membuat tidak teraturnya dalam

pelaksanaan 
6. Volume Ruang Perawatan Kelas III di IRNA II

Ruang perawatan kelas III yang ada di IRNA II memiliki ukuran ruang yang berbeda - beda. Hasilnya adalah sebagai berikut :

Tabel 3.10 : Perhitungan Volume Ruang Perawatan Kelas III di IRNA II RSUD Prof. Dr. Margono Soekarjo Purwokerto Tahun 2014

\begin{tabular}{clccc}
\hline No & Ruangan & Kamar & Luas Lantai $\left(\mathrm{m}^{2}\right)$ & Volume $\left(\mathrm{m}^{3}\right)$ \\
\hline 1 & R. Cempaka & Kamar 8 & $72 \mathrm{~m}^{2}$ & $216 \mathrm{~m}^{3}$ \\
2 & R. Kenanga & Kamar 7 & $72 \mathrm{~m}^{2}$ & $216 \mathrm{~m}^{3}$ \\
3 & R. Seruni & Kamar 7 & $60 \mathrm{~m}^{2}$ & $180 \mathrm{~m}^{3}$ \\
4 & R. Teratai & Kamar 8 & $72 \mathrm{~m}^{2}$ & $216 \mathrm{~m}^{3}$ \\
5 & $\begin{array}{l}\text { R. Edelweis } \\
\text { Perempuan }\end{array}$ & Kamar 3 & $60 \mathrm{~m}^{2}$ & $180 \mathrm{~m}^{3}$ \\
6 & R. Bougenvil & Kamar 2 & $60 \mathrm{~m}^{2}$ & $180 \mathrm{~m}^{3}$
\end{tabular}

\section{PEMBAHASAN}

A. Gambaran Umum RSUD Prof. Dr. Margono Soekarjo Purwokerto

RSUD Prof. Dr. Margono Soekarjo Purwokerto semula merupakan RSU Purwokerto yang berlokasi di Jl. Dr. Angka No. 2 Purwokerto. Awalnya RSU Purwokerto RS Tipe C menempati tanah seluas $3,5 \mathrm{Ha}$. Bangunan RSU Purwokerto ini pada jaman penjajahan sekitar tahun 1923 dikenal sebagai RS Zending yang digunakan sebagai tempat pelayanan kesehatan bagi orang belanda dan misionaris yang berada di sekitar Purwokerto. Pada tahun 1985 RSU Purwokerto ditingkatkan menjadi kelas B Non Pendidikan.

Fungsionalisasi lokasi RSUD Prof. Dr. Margono Soekarjo Purwokerto diresmikan secara keseluruhan pada tanggal 12 November 1995. RSUD Prof. Dr. Margono Soekarjo Purwokerto adalah Rumah Sakit Tipe B Pendidikan milik Pemerintah Provinsi Jawa Tengah yang berada di Purwokerto, wilayah kabupaten Banyumas. RSUD Prof. Dr. Margono Soekarjo Purwokerto menempati bangunan diatas areal tanah seluas 11,5 ha. Secara geografis RSUD Prof. Dr. Margono Soekarjo Purwokerto terletak di Jl. Gumbreg Nomor 1 Purwokerto.

Sebagai Rumah Sakit Tipe B Pendidikan, RSUD Prof. Dr. Margono Soekarjo Purwokerto diharapkan dapat berperan sebagai rumah sakit rujukan tingkat kedua bagi institusi pelayanan kesehatan yang lebih rendah disekitarnya, dan dapat memberikan pelayanan kesehatan paripurna yang terjangkau sesuai dengan tuntutan masyarakat, serta mampu melaksanakan pendidikan profesi kedokteran dan profesi kesehatan lainnya.

1. Tenaga Kerja di RSUD Prof. Dr. Margono Soekarjo Purwokerto

RSUD Prof. Dr. Margono Soekarjo Purwokerto merupakan rumah sakit umum tipe $B$ yang memiliki jumlah tenaga kerja atau pegawai yang cukup banyak dengan jumlah 1.851 orang. Yang terdiri dari tenaga kerja Pegawai Negeri Sipil (PNS) dan tenaga kerja Non Pegawai Sipil (Non PNS). Dengan jumlah tenaga kerja sebanyak ini diharapkan adanya peningkatan pelayanan di rumah sakit, karena pelayanan yang baik oleh tenaga kerja dapat meningkatkan mutu dan kualitas rumah sakit.

Agar tercapainya kinerja yang baik antar pegawai, maka pihak rumah sakit membagi beberapa shift dalam jam kerja. Adapun pembagian shift untuk perawat dan bidan terbagi memjadi 3 shift yaitu shift pagi, siang dan malam.

2. Kapasitas Tempat Tidur RSUD Prof. Dr. Margono Soekarjo Purwokerto

Menurut Depkes ( 2005 ), syarat nilai BOR (Bed Occupancy Rate) adalah60\% $80 \%$. Nilai BOR (Bed Occupancy Rate) RSUD Prof. Dr. Margono Soekarjo Purwokerto pada bulan April 2014 adalah $96,34 \%$, sedangkan untuk jumlah tempat tidur sebanyak 676 tempat tidur. Berdasarkan hasil pengamatan diatas, bahwa nilai BOR RSUD Prof. Dr. Margono Soekarjo Purwokerto pada bulan April 2014 lebih besar dari syarat yang berlaku. Walaupun dengan jumlah tempat tidur yang banyak tersebut diharapkan bisa menampung lebih banyak lagi pasien sehingga kesejahteraan pasien dapat terpenuhi, akan tetapi perlu adanya pengawasan ketat agar tidak memasukkan pasien ke ruang perawatan terlebih dahulu sebelum desinfeksi ruang. Hal tersebut untuk memenuhi kesejahtraan dan kenyamanan terhadap pasien.

\section{B. Data Khusus}

1. IRNA II di RSUD Prof. Dr. Margono Soekarjo Purwokert

Instalasi Rawat Inap atau yang biasa disingkat IRNA, dibagi menjadi dua, yaitu IRNA I dan IRNA II. Perbedaan dari IRNA I dengan IRNA II adalah dalam penanganan penyakit dan pelayanannya.IRNA I memberikan layanan untuk pasien yang terkena penyakit non bedah atau tidak dilakukan pembedahan pada pasien tersebut, sedangkan IRNA II memberikan 
pelayanan pada pasien yang harus mengalami pembedahan pada organ tubuhnya seperti pemasangan Pen, terkena penyakit tumor yang harus mengalami pembedahan. Pada IRNA II terdapat 6 jenis ruang perawatan yaitu ruang perawatan Kenanga, Cempaka, Teratai, Seruni, Bougenvil ( pria dan wanita ), dan Edelweis. Masing- masing jenis ruangan tersebut memiliki 3 kelas, yaitu kelas I, kelas II, dan kelas III.

Dari ke enam jenis ruangan tersebut, yang diambil untuk penelitian adalah kelas III. Di masing-masing ruangan yang ada di kelas III terdapat 8 sampai 10 tempat tidur, 10 sampai 11 kursi, 10 meja yang tergabung dengan lemari.

2. Ruang Perawatan Kelas III di IRNA II

Ruang perawatan kelas III merupakan ruangan yang paling luas diantara kelas I dan kelas II dengan luas $60 \mathrm{~m}^{2}$ dan 72 $\mathrm{m}^{2}$. Jumlah tempat tidur pasien pun lebih banyak dari kelas I dan kelas II dengan jumlah 8-10 tiap ruangan. Hal tersebut akan mempengaruhi suhu dan kelembaban pada ruangan tersebut, karena dengan jumlah pasien dan penunggu yang lebih banyak. Pencahayaan yang ada di ruang perawatan kelas III pun kurang memenuhi standar, serta Ventilasi yang tidak dalam kondisi terbuka semua, hal ini yang dapat mempengaruhi pencahayaan,suhu, dan kelembaban. Walaupun luas lubang ventilasi insidentil (dapat dibuka dan ditutup) sudah lebih dari $15 \%$ dari luas lantai, akan tetapi luas lubang ventilasi yang terbuka belum mencapai $15 \%$ untuk standar ruang perawatan.

3. Hasil Pengukuran dan Pemeriksaan Angka Kuman Udara

Menurut KEPMENKES RI No 1204/MENKES/SK/X/2004 tentang persyaratan kesehatan lingkungan rumah sakit yang menerangkan angka kuman diudara diruang perawatan di standarkan 200-500 CFU $/ \mathrm{m}^{3}$. Angka kuman di ruang perawatan kelas III pada saat dilakukan pengukuran diperoleh hasil, yaitu ruang Cempaka kamar $8 \quad\left(351 \mathrm{CFU} / \mathrm{m}^{3}\right)$, ruang kenanga kamar $7\left(104 \mathrm{CFU} / \mathrm{m}^{3}\right)$, ruang seruni kamar 7 (102 $\left.\mathrm{CFU} / \mathrm{m}^{3}\right)$, ruang teratai kamar $8\left(145 \mathrm{CFU} / \mathrm{m}^{3}\right)$, ruang Edelweis Perempuan (49 $\left.\mathrm{CFU} / \mathrm{m}^{3}\right)$, dan ruang Bougenvil kamar $2\left(194 \mathrm{CFU} / \mathrm{m}^{3}\right)$ dengan rata-rata $157,5 \mathrm{CFU} / \mathrm{m}^{3}$. Berdasarkan hasil pengukuran tersebut, jumlah angka kuman yang ada di ruang perawatan kelas III di IRNA II sudah memenuhi syarat.

Menurut Novi Suripatty dkk (2008), bahwa mikroorganisme yang dapat mempengaruhi terjadinya infeksi nosokomial adalah adanya Bakteri, Virus, Fungi, dan Parasit. Penyebaran mikroorganisme di udara bisa berasal dari fenomena lingkungan yaitu partikel debu. Partikel debu biasanya masuk kedalam ruangan melalui sepatu, pakaian, dan karena terbukanya pintu atau ventilasi, serta akibat buruknya kontruksi ventilasi.

Dari hasil pemeriksaan terdapat kuman udara di ruang perawatan kelas III. $\mathrm{Hal}$ ini merupakan indikator adanya pencemaran udara ruang dan adanya bakteri yang ada di udara yang memungkinkan terjadinya infeksi nosokomial. Adanya penghuni diruangan dapat mempengaruhi tingkat pencemaran udara ruangan oleh mikroba. Mikroba terhembuskan dalam bentuk percikan dari hidung dan mulut selama bersin, batuk, dan bercakap-cakap. Ventilasi udara dalam ruangan berfungsi sebagai pengaturan kondisi suhu dan kelembaban. Untuk menurunkan atau mengurangi angka kuman di udara perlu dilakukannya desinfeksi pada ruangan secara kontinyu. Kegiatan lain yang perlu dilakukan adalah menggunakan alat penghawaan nonalami seperti kipas angin.

Analisis statistik dalam penelitian ini menggunakan uji independent sample Ttest, karena untuk mengetahui ada perbedaan atau tidak ada perbedaan antara jumlah angka kuman udara ruang perawatan kelas III di IRNA II RSUD Prof. Dr. Margono Soekarjo Purwokerto. Menurut hasil perhitungan menggunakan SPSS versi 17.00 dengan rumus T-test dependent, diketahui nilai signifikan (2 tailed) lebih kecil dari $\alpha(0,05)$ yaitu 0,015 . Maka $\mathrm{Ha}$ diterima sehingga ada perbedaan yang bermakna antara jumlah angka kuman udara pada ruang kelas III di IRNA II RSUD Prof. Dr. Margono Soekarjo Purwokerto.

Faktor-faktor yang mempengaruhi adanya jumlah angka kuman udara di antara ruang perawatan kelas III di IRNA II RSUD Prof. Dr. Margono Soekarjo Purwokerto antara lain suhu, kelembaban, pencahayaan, luas lubang ventilasi, dan kepadatan hunian di masingmasing ruangan berbeda-beda seperti yang termuat pada tabel $3.4 ; 3.5$; 3.6; 3.7, dan 3.8.

Luas lubang ventilasi yang tidak memenuhi syarat disebabkan karena tidak semua ventilasi terbuka, sehingga menyebabkan suhu,kelembaban, dan pencahayaan tidak memenuhi syarat atau bahkan melebihi syarat yang berlaku. 
Tidak dilaksanakannya desinfektan secara teratur menyebabkan mikroba diruang perawatan bertambah, sedangkan desinfeksi ruangan dilakukan apabila ruang dalam keadaan kosong dan tidak terisi pasien. Sebaiknya ruang perawatan memiliki jadwal pelaksanaan desinfeksi secara teratur dengan didukung pengaturan ruangan untuk pasien baru.

Angka kuman udara diruang perawatan kelas III masih memenuhi syarat, yaitu kurang dari standar yang berlaku (200-500 CFU/m³). Hal tersebut dipengaruhi oleh kondisi sanitasi ruangan yang baik. Dengan kondisi sanitasi ruangan yang baik maka dapat mengurangi angka kuman udara di ruang perawatan.

4. Hasil Pengukuran Kualitas Fisik

a. Suhu Ruangan

Suhu merupakan salah satu faktor yang mempengaruhi pertumbuhan mikroba di udara. Menurut KepMenKes RI No. 1204/MENKES/SK/X/2004 tentang Persyaratan Kesehatan Lingkungan Rumah Sakit yang menerangkan suhu di ruang perawatan distandarkan 22$24{ }^{\circ} \mathrm{C}$.

Suhu di ruang perawatan kelas III pada masing-masing ruangan pada saat dilakukan pengukuran di peroleh hasil $30,9^{\circ} \mathrm{C}$; $29,3{ }^{\circ} \mathrm{C}$; $28,4{ }^{\circ} \mathrm{C}$; 29,3 ${ }^{\circ} \mathrm{C}$; $30,0^{\circ} \mathrm{C}$, dan $29,9^{\circ} \mathrm{C}$. Suhu tertingi pada ruang perawatan kelas III di IRNA II RSUD Prof. Dr. Margono Soekarjo Purwokerto adalah $30,9^{\circ} \mathrm{C}$, suhu terendah adalah $28,4{ }^{\circ} \mathrm{C}$, sedangkan rata-rata suhu adalah $29,63^{\circ} \mathrm{C}$ (tabel 3.4). Berdasarkan hasil diatas dapat dikatakan bahwa suhu di ruang perawatan kelas III di IRNA II tidak memenuhi atau melebihi standar yang telah ditentukan.

Laju pertumbuhan dan total pertumbuhan bakteri sangat dipengaruhi oleh suhu (Michael J Pelczar, E.C.S Chan, 1986). Rentang suhu pertumbuhan adalah rentang antara suhu pertumbuhan minimum dan maksimum dimana bakteri dapat tumbuh dan berkembangbiak. Selain mempengaruhi perkembangbiakan mikroorganisme di udara, suhu juga akan mempengaruhi kenyamanan pasien oleh karena itu perlu dilakukan usaha penyediaan fasilitas penghawaan ruangan seperti kipas angin, exhauster, ataupun AC agar suhu ruangan dapat stabil.
Menurut Lud Waluyo (2007, h. 129) bahwa daya tahan kuman terhadap suhu tidak sama setiap spesies. Spesies mikroba yang berbeda membutuhkan suhu optimal yang sangat beragam untuk pertumbuhannya. Berdasarkan pada daerah aktivitas temperature (suhu), mikroba dapat dibagi menjadi 3 golongan utama yaitu :

1) Mikroba psikrofil, yakni golongan mikroba yang dapat tumbuh pada suhu $0-30{ }^{\circ} \mathrm{C}$, dengan suhu optimum 10-15 ${ }^{\circ} \mathrm{C}$. kebanyakan dari golongan ini tumbuh di tempattempat yang dingin, baik di daratan maupun di lautan.

2) Mikroba mesofil, adalah golongan mikroba yang dapat hidup dengan baik dengan temperature (suhu) 5 $60{ }^{\circ} \mathrm{C}$, sedangkan temperature optimumnya $25-40{ }^{\circ} \mathrm{C}$. Umumnya mikroba ini hidup dalam alat pencernaan.

3) Mikroba termofil, adalah golongan mikroba yang tumbuh ada temperature $\quad 40-80 \quad{ }^{\circ} \mathrm{C}$, dan temperature optimumnya $55-65^{\circ} \mathrm{C}$. Golongan mikroba ini terutama terdapat di sumber-sumber air panas dan tempat-tempat lain yang bertemperatur tinggi.

Ketersediaan ventilasi yang baik, mengupayakan suhu ruang perawatan yang memenuhi standar karena terjadi pertukaran udara di dalam ruangan dan udara tetap segar. Adanya exhauster, kipas angin atau AC juga dapat membantu pengaturan suhu udara dalam ruangan sehingga suhu ruangan akan memenuhi syarat.

b. Kelembaban Ruangan

Kelembaban merupakan salah satu faktor yang mempengaruhi pertumbuhan mikroba di udara. Menurut KepMenKes RI No. 1204/MENKES/SK/X/2004 tentang Persyaratan Kesehatan Linngkungan Rumah Sakit yang menerangkan kelembaban di ruang perawatan distandarkan $45-60 \%$.

Kelembaban di ruang perawatan kelas III setalah dilakukan pengukuran diperoleh hasil 66,5\%; 70,5\%; 68,5\%; $68,2 \%$; $70,3 \%$, dan $70,3 \%$. Kelembaban tertinggi pada ruang perawatan kelas III di IRNA II RSUD Prof. Dr. Margono Soekarjo Purwokerto adalah $70,5 \%$, kelembaban terendah adalah $66,5 \%$, sedangkan rata-rata kelembaban adalah 69,05\% (tabel 3.5). 
Berdasarkan hasil diatas bisa dikatakan bahwa kelembaban pada saat pengukuran melebihi memenuhi standar yang sudah ditentukan.

Menurut Novy Suripatty (2008) bahwa tingkat kelembaban udara yang tinggi didalam ruangan akan membantu bakteri dalam berkembangbiak. Apabila kelembaban relatife didalam ruangan yang sedang dipergunakan lebih besar dari $60 \%$ maka akan mendorong terjadinya pertumbuhan mikroorganisme pathogen. Keadaan inilah yang memicu terjadinya infeksi nosokomial yang membahayakan pasien, petugas rumah sakit maupun pengunjung.

c. Pencahayaan Ruangan

Pencahayaan merupakan salah satu faktor yang mempengaruhi pertumbuhan mikroba di udara. Menurut KepMenKes RI No. 1204/MENKES/SK/X/2004 tentang Persyaratan Kesehatan Linngkungan Rumah Sakit yang menerangkan pencahayaan di ruang perawatan distandarkan 100-200 Lux.

Pencahayaan di ruang perawatan kelas III di IRNA II terdiri dari pencahayaan alami yaitu dari sinar matahari dan pencahayaan buatan yaitu dari penerangan lampu yang ada di ruang perawatan kelas III. Setalah dilakukan pengukuran dengan kondisi lampu penerangan dinyalakan semua diperoleh hasil 96 Lux, 69 Lux, 80 Lux, 159 Lux, 251 Lux, dan 80 Lux. Pencahayaan tertingi pada ruang perawatan kelas III di IRNA II RSUD Prof. Dr. Margono Soekarjo Purwokerto adalah 251 Lux, pencahayaan terendah adalah $80 \mathrm{Lux}$, sedangkan rata-rata pencahayaan adalah 122,5 Lux. Berdasarkan hasil diatas bisa dikatakan bahwa pencahayaan pada saat dilakukan pengukuran sudah memenuhi standar yang sudah ditentukan.

Di ruang perawatan kelas III di IRNA II sistem penerangan buatan menggunakan lampu TL 20 watt sebanyak 6 buah. Pencahayaan yang kurang merupakan kondisi yang disukai bakteri karena dapat tumbuh baik pada kondisi yang gelap. Cahaya sangat berpengaruh pada proses pertumbuhan bakteri. Umumnya cahaya merusak sel mikroorganisme yang tidak berklorofil. Cahaya mempunyai pengaruh germisida. Sinar ultraviolet dapat menyebabkan terjadinya ionisasi komponen sel yang berakibat menghambat laju pertumbuhan atau menyebabkan kematian.

d. Luas Lubang Ventilasi

Ventilasi mempunyai fungsi untuk menjaga agar aliran udara di dalam ruangan tetap segar, fungsi lain dari ventilasi adalah untuk menjaga kelembaban udara agar kelembaban udara di dalam ruangan tetap stabil, karena kelembaban yang tinggi dapat menjadi media yang baik bagi bakteri terutama bakteri pathogen. Ruang perawatan kelas III di IRNA II memiliki luas vetilasi $1,08 m^{2}$ (R. Cempaka, $R$. Kenanga, dan R. Teratai) dan $0,72 \mathrm{~m}^{2}$ ( R. Seruni, R Edelweis Perempuan, dan R. Bougenvil). Setiap ruang perawatan memiliki 12-18buah ventilasi besar dan 14-18 ventilasi kecil.

e. Kepadatan Hunian

Ruang perawatan kelas III di IRNA II memiliki ukuran ruang $12 \mathrm{~m} \times 6 \mathrm{~m} \times 3$ $\mathrm{m}$ dengan volume ruang $216 \mathrm{~m} 3$. Menurut KepMenKes No. 1204/SK/X/2004 Tentang Persyaratan Kesehatan Lingkungan Rumah Sakit menjelaskan bahwa untuk ruang perawatan dewasa minimal 4,5 $\mathrm{m}^{2} /$ tempat tidur. Sehingga dalam ruang perawatan maksimal terdapat 3 orang. 1 orang pasien dan 2 orang penunggu. Kepadatan hunian pada ruang perawatan kelas III di IRNA II setelah dilakukan penghitungan diperoleh hasil rata-rata kepadatan hunian yaitu 17,56 $\mathrm{m}^{2} /$ orang dengan jumlah kepadatan hunian tertinggi ada diruang Edelweis perempuan dengan 60 m²/orang, sedangkan jumlah kepadatan hunian terendah yaitu ada diruang Cempaka kamar 8 dengan 4,5 $\mathrm{m}^{2} /$ orang. Perabot yang ada di dalam ruang perawatan kelas III di IRNA II adalah 8-10 tempat tidur, almari,10 meja, dan 10-12 kursi.

5. Desinfeksi

RSUD Prof. Dr. Margono Soekarjo dalam melakukan desinfeksi ruangan menggunakan desinfektan yang mengandung bahan aktif Didecyidimethilammonium chloride, Polyhexamethylene Hydrochloride, dan Dimeticones. Desinfektan dengan bahan aktif tersebut memiliki kemampuan mikrobiologi untuk bactericidal dan fungisidal. Salah satu kelebihan dari desinfektan tersebut adalah dalam penggunaannya tanpa bahan pengencer sehingga dapat langsung digunakan dan mampu 
membunuh kuman di udara dengan cepat.

Alat yang digunakan untuk desinfeksi adalah Hurricane Model 2786 Ultra. Alat tersebut mampu memuat 4 liter desinfektan. Pelaksanaan desinfeksi hanya dilakukan dari pukul 07.30 WIB sampai dengan 14.00 WIB sesuai jam kerja bagi pihak IPL. Kegiatan desinfeksi ruangan dilaksanakan apabila ada permintaan dari bagian IRNA dan ruangan dalam keadaan kosong (tidak terdapat pasien). Tujuan dari pelaksanaan desinfeksi ruangan adalah untuk mencegah terjadinya infeksi nosokomial yang dapat terjadi antara pasien dengan pengunjung, pasien dengan dokter/petugas kesehatan lainnya, maupun dari pengunjung ke pengunjung. Sebelum ruangan di desinfeksi terlebih dahulu ruangan dibersihkan oleh petugas kebersihan dan selanjutnya petugas desinfeksi juga harus menyiapkan semua peralatan, bahan dan APD yang diperlukan dalam proses desinfeksi seperti mengisi bahan desinfektan ke dalam alat desinfeksi, dalam hal ini tidak ada takaran khusus, selanjutnya buka semua laci meja dan almari yang ada dalam ruangan, tutup semua ventilasi kemudian lakukan desinfeksi ruangan dengan cara berjalan mundur dari depan ke belakang agar petugas tidak terkena kabut dari desinfeksi, semua sudut ruangan harus didesinfeksi dengan baik termasuk kolong bawah tempat tidur pasien dan juga kamar mandi. Waktu desinfeksi tergantung pada tiap volume ruangan, semakin besar volume ruangan maka waktu desinfeksi akan lebih lama, setelah desinfeksi selesai tutup pintu ruangan kemudian tempelkan label pada pintu atau jendela ruangan yang telah didesinfeksi, ruangan yang telah didesinfeksi dapat digunakan kembali setelah 4 jam setelah desinfeksi. Petugas dalam melakukan desinfeksi di RSUD Prof. Dr. Margono Soekarjo Purwokerto sudah menggunakan APD (Alat Pelindung Diri) akan tetapi belum lengkap seperti belum memakai sarung tangan, sehingga oleh karena itu sebaiknya petugas dalam melakukan desinfeksi menggunakan APD secara lengkap Dalam melakukan desinfeksi seperti topi, masker, dan sarung tangan agar pelaksanaan desinfeksi berjalan dengan lancar.
6. Volume Ruang Perawatan Kelas III di IRNA II

Ruang perawatan kelas III yang ada di IRNA II memiliki ukuran ruang yang berbeda - beda. Setelah dilakukan penghitungan volume ruangan pada ruang perawatan kelas III di IRNA II diperoleh hasil untuk ruang Cempaka kamar 8 memiliki volume ruang $216 \mathrm{~m}^{3}$, ruang Kenanga kamar 7; $216 \mathrm{~m}^{3}$, ruang Seruni kamar 7; $180 \mathrm{~m}^{3}$, ruang Teratai kamar 8; $216 \mathrm{~m}^{3}$, ruang Edelweis Perempuan kamar 3; $180 \mathrm{~m}^{3}$, dan ruang Bougenvil kamar $2 ; 180 \mathrm{~m}^{3}$. Tinggi semua ruangan yaitu 3 meter. Perabot yang ada didalam ruang perawatan kelas III di IRNA II masing-masing adalah 8-10 tempat tidur, almari yang tergabung dengan meja berjumlah 8-10, dan kursi.

Dilihat dari volume ruangan yang ada pada pada ruang perawatan kelas III di IRNA II, untuk melakukan desinfeksi ruangan memerlukan waktu dan bahan desinfektan yang lebih banyak.

\section{SIMPULAN DAN SARAN}

\section{A. Simpulan}

1. Penelitian yang telah dilakukan menunjukkan ada perbedaan jumlah angka kuman udara pada ruang perawatan kelas III di IRNA II RSUD Prof. Dr. Margono Soekarjo Purwokerto. Didukung dengan hasil analisa uji $\mathrm{T}$ diperoleh nilai sig (2-tailed) $=0,006<\alpha$ $(0,05)$ maka Ha diterima.

2. Dari hasil penelitian yang dilakukan pada ruang perawatan kelas III di IRNA II RSUD Prof. Dr. Margono Soekarjo Purwokerto didapatkan hasil pengukuran angka kuman pada ruang Cempaka kamar 8; $351 \mathrm{CFU} / \mathrm{m}^{3}$, ruang Kenanga kamar 7; $104 \mathrm{CFU} / \mathrm{m}^{3}$, ruang Seruni kamar 7; $102 \mathrm{CFU} / \mathrm{m}^{3}$, ruang Teratai kamar 8; $145 \mathrm{CFU} / \mathrm{m}^{3}$, ruang Edelweis Perempuan; $49 \mathrm{CFU} / \mathrm{m}^{3}$, dan ruang Bougenvil kamar 2; $194 \mathrm{CFU} / \mathrm{m}^{3}$.

3. Hasil pengukuran suhu, kelembaban, pencahayaan, luas lubang ventilasi, dan kepadatan hunian pada ruang perawatan kelas III di IRNA II RSUD Prof. Dr. Margono Soekarjo Purwokerto, yaitu;

a. Suhu ruang Cempaka kamar 8; 30,9 ${ }^{\circ} \mathrm{C}$, ruang Kenanga kamar $7 ; 29,3^{\circ} \mathrm{C}$, ruang Seruni kamar $7 ; 28,4{ }^{\circ} \mathrm{C}$, ruang Teratai kamar $8 ; 29,3{ }^{\circ} \mathrm{C}$, ruang Edelweis Perempuan; $30,0{ }^{\circ} \mathrm{C}$, dan ruang Bougenvil kamar $2 ; 29,9^{\circ} \mathrm{C}$.

b. Kelembaban ruang Cempaka kamar 8; $66,5 \%$, ruang Kenanga kamar 7; $70,5 \%$, ruang Seruni kamar $7 ; 68,5 \%$, 
ruang Teratai kamar 8; 68,2\%, ruang Edelweis Perempuan; $70,3 \%$, dan ruang Bougenvil kamar 2; 70,3\%.

c. Pencahayaan ruang Cempaka kamar 8; 96 Lux, ruang Kenanga kamar 7; 69 Lux, ruang Seruni kamar 7; 80 Lux, ruang Teratai kamar 8; 159 Lux, ruang Edelweis Perempuan; 251 Lux, dan ruang Bougenvil kamar 2; 80 Lux

d. Luas Lubang Ventilasi ruang Cempaka kamar 8; 21,75\%, ruang Kenanga kamar 7; 13\%, ruang Seruni kamar 7; $10 \%$, ruang Teratai kamar $8 ; 15,75 \%$, ruang Edelweis Perempuan; 9\%, dan ruang Bougenvil kamar 2; 11,6\%

e. Kepadatan Hunian ruang Cempaka kamar 8; 4,5 m²/orang, ruang Kenanga kamar $7 ; 10,2 \mathrm{~m}^{2} /$ orang, ruang Seruni kamar $7 ; 12 \mathrm{~m}^{2} /$ orang, ruang Teratai kamar 8; 12 m²/orang, ruang Edelweis Perempuan; $60 \mathrm{~m}^{2} /$ orang, dan ruang Bougenvil kamar 2; 6,66 m²/orang.

\section{B. Saran}

1. Bagi Rumah Sakit

a. Selalu membuka jendela dan ventilasi sehingga luas lubang ventilasi mencapai $15 \%$ dari luas lantai, agar suhu dan kelembaban memenuhi syarat serta mencegah perkembangan mikroba dalam ruangan.

b. Apabila suhu dan kelembaban belum memenuhi syarat, maka perlu ditambahkan fan/kipas angin.

c. Adanya jadwal pelaksanaan desinfeksi ruangan secara rutin dengan didukung pengaturan ruangan untuk pasien baru, agar ruangan dapat dilakukan desinfeksi.

d. Pada ruangan perawatan kelas III di IRNA II, sebaiknya lampu yang sudah ada selalu dinyalakan hingga nilai pencahayaan mencapai 100-200 Lux.

e. Pada ruang perawatan kelas III di IRNA agar membatasi jumlah pengunjung yang diperbolehkan masuk ruang perawatan, untuk mengurangi resiko bertambahnya jumlah kuman udara.

2. Kepada pihak IPL RSUD Prof. Dr. Margono Soekarjo Purwokerto

a. Tetap melakukan desinfeksi ruangan dengan sistem penyemprotan dengan menggunakan Standar Operasional Prosedur (SOP) yang baik dan benar.

b. Petugas pada saat melakukan proses desinfeksi sebaiknya menggunakan alat pelindung diri berupa masker dan pakaian kerja serta sarung tangan.

3. Bagi Peneliti Lain

Sebaiknya peneliti lain untuk mengembangkan dan memperluas wawasan dengan menambah jumlah variabel yang akan diteliti, agar mengetaui perbedaan jumlah angka kuman udara dikelas yang berbeda.

\section{DAFTAR PUSTAKA}

Depkes RI . 2004. Menteri Kesehatan Republik Indonesia Nomor 1204/MENKES/SK/X/2004. Persyaratan Kesehatan Lingkungan Rumah Sakit

DepKes RI, 2010, Keputusan Menteri Kesehatan Republik Indonesia Nomor: 340/MENKES/PER/III/X/2010 Tentang Klasifikasi Rumah Sakit Berdasarkan Fasilitas Dan Kemampuan Pelayanan, Jakarta Departemen Kesehatan RI

Depkes RI. 2002. Menteri Kesehatan Republik Indonesia Nomor 1335/MENKES/SK/X/2002. Standar Operasional Pengambilan dan Pengukuran Sampel Kualitas Udara Rumah Sakit

Depkes RI. 2009. Undang-Undang Republik Indonesia Nomor 36 Tahun 2009. Kesehatan

Depkes RI. 2009. Undang-Undang Republik Indonesia Nomor 44 Tahun 2009.Rumah Sakit

Dyah Moriska Candra, 2012 Studi Komparasi Jumlah Angka Kuman Udara Ruang Perawatan Kenanga Kelas 2 dan 3 di RSUD Prof. Dr. Margono Soekarjo Purwokerto, KTI Tahun 2012/2013, purwokerto: jurusan kesehatan lingkungan purwokerto

Djamaluddin Ramlan dan Maisye Marlyn Kuhu, 2013, Penulisan penelitian Deskriptif, Purwokerto: UPT Percetakan dan Penerbitan Unsoed

Lud Waluyo, 2004, Mikrobiologi Umum, Malang: Universitas Muhammadiyah Malang

Pelczar, M.J dan ECS Chan, 2008, Dasar-Dasar Mikrobiologi, Jakarta: Universitas Indonesia

RSUD Prof. Dr. Margono Soekarjo Purwokerto 2 014, Profil RSMS, diakses at http://www.rsmargono.go.id/ pada tanggal 2 April 2014 pukul 22.30 WIB.

Suparmin, 2008, Hubungan Kualitas Lingkungan Fisik Dengan Angka Kuman Udara Ruang 
Perawatan Di RSUD Prof. Dr. Margono Soekarjo Purwokerto, makalah pada kuliah Perdana Semester genap TA. 2008/2009, Purwokerto : Jurusan kesehatan Lingkungan Purwokerto

Susilowati, 2008, Hubungan Lingkungan Fisik dengan Angka Kuman di Ruang Perawatan Kelas II dan Kelas III RS
Bhakti Wira Tamtama Semarang Tahun 2008, Semarang: Universitas Diponegoro

Tri Cahyono, 2013, Pedoman Penulisan Proposal penelitian dan Karya Tulis Ilmiah/skripsi Edisi revisi ketiga, Purwokerto: Kementrian Kesehatan RI Politeknik Kesehatan Semarang Jurusan Kesehatan Lingkungan Purwokerto 